\title{
Commentary
}

\section{Training infectious diseases fellows for a new era of hospital epidemiology}

\author{
Elise M. Martin MD, MS ${ }^{1,2}$ and Graham M. Snyder MD, SM ${ }^{1,2}$ (1) \\ ${ }^{1}$ Department of Infection Prevention and Control, UPMC Presbyterian, Pittsburgh, Pennsylvania and ${ }^{2}$ Division of Infectious Diseases, Department of Medicine, \\ University of Pittsburgh School of Medicine, Pittsburgh, Pennsylvania
}

\begin{abstract}
Training programs for infectious diseases fellows pursuing a career in infection prevention and control and hospital epidemiology are grounded in mentorship and organizational experience. In this commentary, we propose a competency-based framework for creating structured learning for infectious diseases fellows pursuing hospital epidemiology and related fields.
\end{abstract}

(Received 22 July 2021; accepted 23 July 2021)

\section{Evolving training to match a growing field}

In recent decades, the field of infection prevention and control and healthcare epidemiology (IP\&C/HE) has expanded considerably. ${ }^{1}$ IP\&C/HE programs are not only responsible for surveillance and prevention of healthcare-associated infections (HAIs), they also conduct cluster investigations, contribute to emergency preparedness, engage in quality improvement efforts, and partner with patient safety, occupational health, and environmental health and safety teams. They employ diagnostic and antimicrobial stewardship strategies, and they develop both patient and staff education. ${ }^{2}$ The coronavirus disease 2019 (COVID-19) pandemic has only further highlighted the important roles of IP\&C/HE and healthcare epidemiologists. ${ }^{3,4}$

As the field of IP\&C/HE evolves in an increasingly complex healthcare environment, more demands are made on the healthcare epidemiologists who lead these programs. ${ }^{5}$ When IP\&C programs were first developed, the physician team members made contributions from different backgrounds, including infectious diseases (ID), pathology, and microbiology, and not all had formal training in hospital epidemiology. These programs also varied in the amount of time dedicated. ${ }^{5-7}$ Although there is no formal accreditation process for healthcare epidemiologists, more ID physicians are seeking specific fellowship training in IP\&C with the goal of a career in infection prevention as a healthcare epidemiologist, and healthcare facilities are offering positions with protected time to lead IP\&C programs.

\section{Existing training resources}

There is no Accreditation Council for Graduate Medical Education (ACGME) fellowship, other formal accreditation, or certification process for training to be a healthcare epidemiologist. The

Author for correspondence: Graham Snyder, MD, Falk Medical Building, 3601 Fifth Ave, Suite 150, Pittsburgh, PA 15213. E-mail: snydergm3@upmc.edu

Cite this article: Martin EM and Snyder GM. (2021). Training infectious diseases fellows for a new era of hospital epidemiology. Antimicrobial Stewardship \& Healthcare Epidemiology, https://doi.org/10.1017/ash.2021.186
ACGME requires all ID fellows to have some training in infection prevention, including competence in the diagnosis and management of HAI and device-associated infections, as well as infections, as well as general knowledge of infection control and hospital epidemiology. ${ }^{8}$

Other educational opportunities include the Society for Healthcare Epidemiology of America (SHEA)/Centers for Disease Control and Prevention (CDC) Training Certification in Healthcare Epidemiology, ${ }^{9}$ the SHEA Primer on Healthcare Epidemiology, Infection Control, and Antimicrobial Stewardship (online ID fellows' course), ${ }^{10}$ and the Annual Fellows' Course in Healthcare Epidemiology, Infection Prevention, and Antimicrobial Stewardship (in-person course). ${ }^{11}$

Most ID fellows interested in a career in infection prevention seek out ID fellowship programs comprising an experienced hospital epidemiologist mentor and a strong IP\&C program with a history of training ID fellows who have successfully launched careers as healthcare epidemiologists. Some of these programs have defined tracks in IP\&C and may offer a third year of fellowship dedicated to additional IP\&C training and research. The last SHEA membership survey published in 2010 found that while nearly $60 \%$ of respondents reported completing the SHEA/CDC training course, only $26 \%$ completed at least 1 year of dedicated IP\&C training. ${ }^{5}$

At a series of national meetings, ID division chiefs and program directors recommended either a 1-month rotation in IP\&C and/or course involving a combination of didactic and/or practical IP work. ${ }^{12}$ They did not define what should be included in the rotation or the didactics. Subsequent surveys of both adult and pediatric ID fellows and recent graduates highlighted the importance but shortcomings of IP\&C training during fellowship. Only half of adult ID fellowship respondents thought IP\&C training was adequate, and pediatric ID fellowships were reported to be deficient in both the breadth and depth of IP\&C training in most programs. ${ }^{13,14}$ In at least one institution's published experience, a month-long semistructured rotation can be successful in improving IP\&C education among ID fellows. ${ }^{15}$

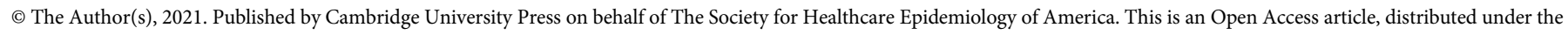

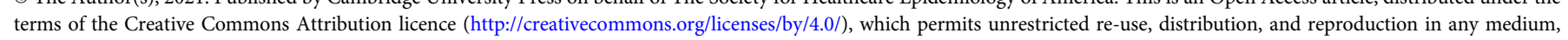
provided the original work is properly cited. 
Table 1. Infectious Diseases Fellowship Infection Prevention \& Control/Hospital Epidemiology Rotation and Track Core Competencies and Activities

\begin{tabular}{|c|c|c|c|}
\hline Competency & Activities & Rotation & Track \\
\hline \multicolumn{4}{|l|}{ Surveillance and Reporting } \\
\hline $\begin{array}{l}\text { Understand how healthcare-associated infection (HAI) surveillance } \\
\text { is conducted }\end{array}$ & $\begin{array}{l}\text { Observe infection preventionists (IP) reviewing microbiology results } \\
\text { and applying NHSN definitions for the following: } \\
\text { - Central-line-associated bloodstream infection (CLABSI) } \\
\text { - Catheter-associated urinary tract infection (CAUTI) } \\
\text { - Surgical site infection (SSI) } \\
\text { - Ventilator-associated event (VAE) } \\
\text { - Clostridioides (Clostridium) difficile and multidrug-resistant } \\
\text { organisms }\end{array}$ & $\checkmark$ & $\checkmark$ \\
\hline Consider methods of validation and auditing of HAI data & $\begin{array}{l}\text { Discuss the internal validation of HAI data } \\
\text { Identify the opportunities for external validation of HAI data }\end{array}$ & & 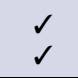 \\
\hline $\begin{array}{l}\text { Review the advantages and limitations of surveillance software in } \\
\text { the process of HAI surveillance }\end{array}$ & $\begin{array}{l}\text { Review with IP data analyst or informatics team members the } \\
\text { sources of surveillance data } \\
\text { Review the SHEA research methods white paper on administrative } \\
\text { and surveillance data }\end{array}$ & & $\begin{array}{l}\checkmark \\
\checkmark\end{array}$ \\
\hline $\begin{array}{l}\text { Distinguish between HAl surveillance and clinical definitions for } \\
\text { infectious syndromes }\end{array}$ & $\begin{array}{l}\text { Participate in a multidisciplinary discussion, quality review, or } \\
\text { teaching session that includes case-based review describing } \\
\text { surveillance-identified } \mathrm{HAl}\end{array}$ & $\checkmark$ & $\checkmark$ \\
\hline $\begin{array}{l}\text { Understand and effectively utilize various HAI measures including } \\
\text { numerator and denominator, and counts, rates, and adjusted rates }\end{array}$ & $\begin{array}{l}\text { As part of routine IP work or project work, present HAI outcome } \\
\text { data with appropriate case ascertainment, at-risk population, and } \\
\text { consideration of risk adjustment }\end{array}$ & $\checkmark$ & $\checkmark$ \\
\hline $\begin{array}{l}\text { Evaluate facility performance on } \mathrm{HAI} \text { and } \mathrm{HAI} \text { prevention process } \\
\text { measures using internal and external benchmarks }\end{array}$ & $\begin{array}{l}\text { For at least } 1 \mathrm{HAl} \text {, consider and discuss internal and external } \\
\text { benchmarking options }\end{array}$ & $\checkmark$ & $\checkmark$ \\
\hline $\begin{array}{l}\text { Consider the role of } \mathrm{HAl} \text { in the context of other patient safety } \\
\text { events, including falls, pressure ulcers, and other adverse outcomes }\end{array}$ & $\begin{array}{l}\text { Attend } \geq 1 \text { patient safety or hospital quality meeting, and compare } \\
\text { and contrast infection-related and non-infection-related outcomes } \\
\text { including reporting, benchmarking, and improvement interventions }\end{array}$ & & $\checkmark$ \\
\hline $\begin{array}{l}\text { Review requirements for reporting community- and healthcare- } \\
\text { associated infections to public health }\end{array}$ & $\begin{array}{l}\text { Review state and local health department reporting requirements } \\
\text { Observe IP processes for identifying reportable illnesses and } \\
\text { performing reporting }\end{array}$ & $\begin{array}{l}\checkmark \\
\checkmark\end{array}$ & $\begin{array}{l}\checkmark \\
\checkmark\end{array}$ \\
\hline \multicolumn{4}{|l|}{ Cluster detection, investigation, and resolution } \\
\hline $\begin{array}{l}\text { Describe what defines an epidemiologically significant cluster, } \\
\text { including differences in cluster detection among pathogens }\end{array}$ & $\begin{array}{l}\text { Participate in the investigation and response to a single case of an } \\
\text { epidemiologically significant pathogen, such as vancomycin } \\
\text { nonsusceptible Staphylococcus aureus, carbapenem-resistant } \\
\text { Enterobacteriaceae, Candida auris, Legionella, invasive mold, or } \\
\text { SARS-CoV-2 } \\
\text { (If no case is available, describe pathogens for which } 1 \text { or a few } \\
\text { cases define an outbreak and those for whom clusters are } \\
\text { differentiated from endemic rates) }\end{array}$ & $\checkmark$ & $\checkmark$ \\
\hline $\begin{array}{l}\text { For a multiple-case cluster, understand the application of multiple } \\
\text { steps of an outbreak investigation }\end{array}$ & $\begin{array}{l}\text { Participate in the investigation of a HAl cluster } \\
\text { (If no cluster is available, describe from the published literature at } \\
\text { least } 1 \text { description of an outbreak investigation) }\end{array}$ & $\checkmark$ & $\checkmark$ \\
\hline $\begin{array}{l}\text { Understand the roles of case-control or cohort study in identifying } \\
\text { potential transmission routes leading to a cluster of infections }\end{array}$ & $\begin{array}{l}\text { Perform a case-control or cohort study as part of a cluster } \\
\text { investigation } \\
\text { Describe the findings of a cluster investigation to stakeholders and } \\
\text { hospital leadership, including proposed or enacted changes to } \\
\text { baseline prevention practices }\end{array}$ & & $\begin{array}{l}-1 \\
\checkmark \\
\checkmark\end{array}$ \\
\hline $\begin{array}{l}\text { Describe the role that identification of genetic relatedness plays in } \\
\text { cluster identification, and understand commonly used techniques } \\
\text { from antimicrobial phenotype to molecular typing and } \\
\text { whole-genome sequencing (WGS) }\end{array}$ & $\begin{array}{l}\text { Participate in a meeting where the use of WGS is considered for a } \\
\text { possible cluster and/or results are reviewed } \\
\text { Review } \geq 2 \text { published articles of healthcare-associated outbreaks } \\
\text { and be able to describe the methods used to establish genetic } \\
\text { relatedness }\end{array}$ & $\begin{array}{l}-10 \\
\checkmark \\
\checkmark\end{array}$ & $\begin{array}{l}-10 \\
\checkmark \\
\checkmark\end{array}$ \\
\hline $\begin{array}{l}\text { Understand the key elements of an exposure investigation: } \\
\text { identifying patients and providers potentially exposed; incubation } \\
\text { period; postexposure measures including prophylaxis, vaccination, } \\
\text { monitoring, furlough }\end{array}$ & $\begin{array}{l}\text { Assist in an exposure investigation (eg, tuberculosis, varicella } \\
\text { zoster, SARS-CoV-2) in conjunction with the infection preventionist }\end{array}$ & & $\checkmark$ \\
\hline $\begin{array}{l}\text { Consider the role of active surveillance testing in the prevention of } \\
\text { multidrug-resistant organisms }\end{array}$ & $\begin{array}{l}\text { Compare published observational or clinical trial with institutional } \\
\text { practice for } \geq 1 \text { multidrug-resistant pathogen such as methicillin- } \\
\text { resistant S. aureus, vancomycin-resistant enterococci, or } \\
\text { carbapenem-resistant Enterobacteriaceae }\end{array}$ & $\checkmark$ & $\checkmark$ \\
\hline
\end{tabular}


Table 1. (Continued)

\begin{tabular}{|c|c|c|c|}
\hline Competency & Activities & Rotation & Track \\
\hline \multicolumn{4}{|l|}{ Pathogen transmission and transmission interruption } \\
\hline Understand modes of pathogen transmission & $\begin{array}{l}\text { Be able to describe the common and potential modes of } \\
\text { transmission of healthcare-associated pathogens }\end{array}$ & $\checkmark$ & $\checkmark$ \\
\hline $\begin{array}{l}\text { Describe the rationale for transmission-based precautions for } \\
\text { pathogens commonly observed in the healthcare setting }\end{array}$ & $\begin{array}{l}\text { Review the CDC guideline "Type and Duration of Precautions } \\
\text { Recommended for Selected Infections and Conditions" and } \\
\text { compare these to institutional practices }\end{array}$ & $\checkmark$ & $\checkmark$ \\
\hline $\begin{array}{l}\text { Identify clinical situations for which standard precautions (and } \\
\text { specific elements of standard precautions) should be employed }\end{array}$ & $\begin{array}{l}\text { Perform with infection preventionists observations of personal } \\
\text { protective equipment use }\end{array}$ & $\checkmark$ & $\checkmark$ \\
\hline $\begin{array}{l}\text { Hand hygiene: understand the evidence base for hand hygiene as } \\
\text { an infection prevention tool to reduce transmission in the } \\
\text { healthcare setting }\end{array}$ & $\begin{array}{l}\text { Review the World Health Organization guidelines on hand hygiene, } \\
\text { and describe at least } 1 \text { high-quality study of the effectiveness of } \\
\text { hand hygiene }\end{array}$ & $\checkmark$ & $\checkmark$ \\
\hline $\begin{array}{l}\text { Hand hygiene: observe the measurement and feedback of hand } \\
\text { hygiene adherence }\end{array}$ & $\begin{array}{l}\text { Participate in hand hygiene observations with a member of the } \\
\text { IP team } \\
\text { Conduct independent observations of hand hygiene adherence and } \\
\text { provide feedback to observed units }\end{array}$ & $\checkmark$ & $\begin{array}{l}\checkmark \\
\checkmark\end{array}$ \\
\hline $\begin{array}{l}\text { Hand hygiene: understand interventions that may be employed to } \\
\text { improve hand hygiene adherence in the acute care setting }\end{array}$ & Plan a unit-based intervention to improve hand hygiene adherence & & $\checkmark$ \\
\hline $\begin{array}{l}\text { Be able to describe interventions to prevent catheter-related } \\
\text { bloodstream infections }\end{array}$ & $\begin{array}{l}\text { Compare and contrast institutional policies with evidence-based } \\
\text { practices in SHEA Compendium of Strategies to prevent central- } \\
\text { line-associated bloodstream infections }\end{array}$ & $\checkmark$ & $\checkmark$ \\
\hline $\begin{array}{l}\text { Be able to describe interventions to prevent catheter-related urinary } \\
\text { tract infections }\end{array}$ & $\begin{array}{l}\text { Compare and contrast institutional policies with evidence-based } \\
\text { practices in SHEA Compendium of Strategies to prevent catheter- } \\
\text { associated urinary tract infections }\end{array}$ & $\checkmark$ & $\checkmark$ \\
\hline $\begin{array}{l}\text { Be able to describe interventions to prevent ventilator-associated } \\
\text { events }\end{array}$ & $\begin{array}{l}\text { Compare and contrast institutional policies with evidence-based } \\
\text { practices in SHEA Compendium of Strategies to prevent ventilator- } \\
\text { associated infections }\end{array}$ & $\checkmark$ & $\checkmark$ \\
\hline Be able to describe interventions to prevent surgical site infections & $\begin{array}{l}\text { Compare and contrast institutional policies with evidence-based } \\
\text { practices in SHEA Compendium of Strategies to prevent surgical } \\
\text { site infections }\end{array}$ & $\checkmark$ & $\checkmark$ \\
\hline $\begin{array}{l}\text { Be able to describe interventions to prevent healthcare-associated } \\
\text { infections due to } C \text {. difficile }\end{array}$ & $\begin{array}{l}\text { Compare and contrast institutional policies with evidence-based } \\
\text { practices in SHEA Compendium of Strategies to prevent } C \text {. difficile }\end{array}$ & $\checkmark$ & $\checkmark$ \\
\hline $\begin{array}{l}\text { Consider the risk of transmission from contaminated and } \\
\text { incompletely reprocessed reusable medical equipment }\end{array}$ & $\begin{array}{l}\text { Perform an observation of clinical care on } \geq 1 \text { unit, and propose an } \\
\text { intervention to reduce the risk of device contamination }\end{array}$ & $\checkmark$ & $\checkmark$ \\
\hline $\begin{array}{l}\text { Understand the steps for reprocessing, and quality assurance of } \\
\text { reprocessing adequacy, of devices requiring high-level disinfection } \\
\text { and sterilization }\end{array}$ & $\begin{array}{l}\text { Participate in observations of } 1 \text { or more reprocessing events: } \\
\text { - Survey the reprocessing program in the sterile processing } \\
\text { department } \\
\text { - Observe the reprocessing of a duodenoscope and assist in } \\
\text { performing duodenoscope cultures } \\
\text { - Conduct high-level disinfection regulatory rounds with the infection } \\
\text { preventionist and regulatory team }\end{array}$ & & $\checkmark$ \\
\hline \multicolumn{4}{|l|}{ Environment of care } \\
\hline $\begin{array}{l}\text { Observe water safety measures including Legionella water } \\
\text { monitoring }\end{array}$ & $\begin{array}{l}\text { Conduct water quality surveillance with IP } \\
\text { Participate in a water quality/safety meeting }\end{array}$ & $\begin{array}{l}\checkmark \\
\checkmark\end{array}$ & $\begin{array}{l}\checkmark \\
\checkmark\end{array}$ \\
\hline $\begin{array}{l}\text { Environmental cleaning-understand the evidence to support the } \\
\text { relationship between environmental contamination and pathogen } \\
\text { transmission }\end{array}$ & $\begin{array}{l}\text { Review at least } 1 \text { published article of transmission from prior room } \\
\text { occupant and/or environmental cultures and pathogen acquisition }\end{array}$ & $\checkmark$ & $\checkmark$ \\
\hline $\begin{array}{l}\text { Environmental cleaning-observe the evaluation of quality of } \\
\text { environmental cleaning, and understand potential methods to } \\
\text { assess environmental cleaning }\end{array}$ & $\begin{array}{l}\text { Participate in environmental cleaning observations with } \\
\text { environmental services (after discharge cleaning) or infection } \\
\text { prevention (special case) } \\
\text { Review the literature for evidence to support the use of fluorescent } \\
\text { marker, adenosine triphosphate, visual inspection, and } \\
\text { microbiologic cultures }\end{array}$ & & $\begin{array}{l}\checkmark \\
\checkmark\end{array}$ \\
\hline $\begin{array}{l}\text { Environmental cleaning-understand the potential role for } \\
\text { no-touch disinfection in reducing pathogen transmission }\end{array}$ & $\begin{array}{l}\text { Review the BETR trial and current hospital practices for the use of } \\
\text { no-touch disinfection }\end{array}$ & & $\checkmark$ \\
\hline $\begin{array}{l}\text { Understand the methods by which Infection Prevention mitigates } \\
\text { the risk of transmission (including pertinent pathogens involved) } \\
\text { resulting from construction in acute care settings }\end{array}$ & $\begin{array}{l}\text { Participate in observation of construction risk assessment rounds } \\
\text { with an infection preventionist }\end{array}$ & $\checkmark$ & $\checkmark$ \\
\hline $\begin{array}{l}\text { Air management-be able to describe the role of airborne isolation } \\
\text { for select pathogens including tuberculosis, and the difference in } \\
\text { clinical and infection prevention-related risk assessments }\end{array}$ & $\begin{array}{l}\text { Participate in IP team discussions related to the removal of } \\
\text { precautions for a potential case of tuberculosis }\end{array}$ & $\checkmark$ & $\checkmark$ \\
\hline
\end{tabular}


Table 1. (Continued)

\begin{tabular}{|c|c|c|c|}
\hline Competency & Activities & Rotation & Track \\
\hline $\begin{array}{l}\text { Advanced air management_-understand advanced principles } \\
\text { related to air management including monitoring negative pressure, } \\
\text { airflow in surgical settings, UV disinfection }\end{array}$ & $\begin{array}{l}\text { Consider in depth at least one advanced risk and related mitigation } \\
\text { measures in use at the facility }\end{array}$ & & $\checkmark$ \\
\hline $\begin{array}{l}\text { Understand the role of life safety (environmental health and safety) } \\
\text { in preventing infection- and non-infection-related adverse events }\end{array}$ & $\begin{array}{l}\text { Identify at least } 1 \text { condition for which life safety standards may } \\
\text { differ from standards recommended solely for infection } \\
\text { prevention-related purposes }\end{array}$ & & $\checkmark$ \\
\hline \multicolumn{4}{|l|}{ Quality improvement: Principles and practice } \\
\hline Understand the role of regulatory structure and oversight & $\begin{array}{l}\text { Attend } \geq 1 \text { multidisciplinary meeting that includes a discussion of } \\
\text { quality improvement and accountability related to } \geq 1 \text { infection- } \\
\text { related quality measure(s) }\end{array}$ & $\checkmark$ & $\checkmark$ \\
\hline $\begin{array}{l}\text { Improvement tools: learn how root cause analysis and the steps of } \\
\text { plan-do-study-act (PDSA) cycles are used to reduce risk of HAls }\end{array}$ & $\begin{array}{l}\text { Consider the application of PDSA cycles for at least } 1 \text { HAl type } \\
\text { Observe a discussion of an HAI root cause analysis conducted by } \\
\text { infection preventionists or quality team }\end{array}$ & $\begin{array}{l}-1 \\
\checkmark \\
\checkmark\end{array}$ & $\begin{array}{l}-1 \\
d \\
\checkmark\end{array}$ \\
\hline $\begin{array}{l}\text { Improvement tools: learn how advanced techniques are applied to } \\
\text { reduce HAI } \\
\text { - PDSA, lean, six sigma } \\
\text { - Implementation science } \\
\text { - Human factor design } \\
\text { - Organizational change } \\
\text { - Failure modes and effect analysis } \\
\text { - Root cause analysis }\end{array}$ & $\begin{array}{l}\text { Review educational material related to advanced techniques in } \\
\text { quality improvement } \\
\text { Participate in an ongoing or new quality improvement project in } \\
\text { which } 1 \text { or more quality improvement techniques are applied }\end{array}$ & & 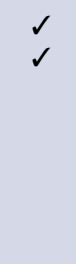 \\
\hline $\begin{array}{l}\text { Statistical methods in IP_-understand the analytic methods used } \\
\text { for quasi-experimental and observational studies }\end{array}$ & $\begin{array}{l}\text { Review the SHEA research methods white papers on } \\
\text { quasi-experimental studies and observational studies }\end{array}$ & $\checkmark$ & $\checkmark$ \\
\hline $\begin{array}{l}\text { Statistical methods in IP_-understand the analytic methods used } \\
\text { for randomized controlled trials, mixed methods studies, } \\
\text { mathematical modeling }\end{array}$ & $\begin{array}{l}\text { Review the SHEA research methods white papers on randomized } \\
\text { controlled trials, mixed methods studies, and mathematical } \\
\text { modeling } \\
\text { Apply principles described in any of the SHEA research methods } \\
\text { white papers to a research project }\end{array}$ & & $\begin{array}{l}-1 \\
\checkmark \\
\checkmark\end{array}$ \\
\hline $\begin{array}{l}\text { Practice effective methods of education for healthcare workers and } \\
\text { patients }\end{array}$ & $\begin{array}{l}\text { Develop and administer at least } 1 \text { educational intervention in } \\
\text { support of either a quality improvement project or HAI reduction } \\
\text { initiative }\end{array}$ & $\checkmark$ & $\checkmark$ \\
\hline \multicolumn{4}{|l|}{ Microbiology laboratory partnership } \\
\hline $\begin{array}{l}\text { Appreciate the role the microbiology laboratory plays in } \\
\text { identification of clinical or environmental surveillance }\end{array}$ & $\begin{array}{l}\text { Participate in at least } 1 \text { multidisciplinary meeting in which cultures } \\
\text { obtained for infection prevention purposes are discussed }\end{array}$ & $\checkmark$ & $\checkmark$ \\
\hline Understand the concept of diagnostic stewardship & $\begin{array}{l}\text { Review ways providers' testing choices are influenced to improve } \\
\text { patient care related to urine cultures and } C \text {. difficile testing, and } \\
\text { other diagnostic tests }\end{array}$ & $\checkmark$ & $\checkmark$ \\
\hline $\begin{array}{l}\text { Understand how test selection and test characteristics may impact } \\
\text { HAI surveillance }\end{array}$ & $\begin{array}{l}\text { Consider for at least } 1 \text { test the sensitivity, specificity, positive } \\
\text { predictive value, and negative predictive value, and be able to } \\
\text { describe the effect of these test characteristics on HAl surveillance } \\
\text { and reporting }\end{array}$ & & $\checkmark$ \\
\hline \multicolumn{4}{|l|}{ Antibiotic stewardship partnership } \\
\hline $\begin{array}{l}\text { Appreciate the resistance profile of bacterial and fungal pathogens } \\
\text { at the institution }\end{array}$ & $\begin{array}{l}\text { Review and interpret the organizational antibiogram, and compare } \\
\text { with rates of multidrug resistance among common HAl pathogens }\end{array}$ & $\checkmark$ & $\checkmark$ \\
\hline $\begin{array}{l}\text { Understand the relatedness between antibiotic use and } \\
\text { multidrug-resistant organisms }\end{array}$ & $\begin{array}{l}\text { For at least } 1 \text { common multidrug-resistant pathogen, compare HAI } \\
\text { rates and antibiotic usage rates for pertinent antimicrobials }\end{array}$ & $\checkmark$ & $\checkmark$ \\
\hline \multicolumn{4}{|l|}{ Occupational health and infection prevention } \\
\hline $\begin{array}{l}\text { Describe the impact of a healthcare worker vaccination policy on } \\
\text { the risk of transmission of pathogens in the workplace }\end{array}$ & $\begin{array}{l}\text { For at least } 1 \text { of the following pathogens, review the healthcare } \\
\text { worker vaccination policy and consider published evidence of } \\
\text { patient-to-HCW transmission in developed settings: influenza, } \\
\text { hepatitis B, measles, mumps, rubella, hepatitis }\end{array}$ & $\checkmark$ & $\checkmark$ \\
\hline $\begin{array}{l}\text { Understand the role of presenteeism in healthcare-to-patient } \\
\text { transmission of respiratory and gastrointestinal infections }\end{array}$ & $\begin{array}{l}\text { Perform observations of healthcare worker behaviors (if rotation } \\
\text { during respiratory virus season) }\end{array}$ & & $\checkmark$ \\
\hline $\begin{array}{l}\text { (See also "Assist in an exposure investigation ...." in section } \\
\text { "Cluster detection, investigation, and resolution") }\end{array}$ & $\cdots$ & $\ldots$ & $\cdots$ \\
\hline \multicolumn{4}{|l|}{ Emergency preparedness } \\
\hline $\begin{array}{l}\text { Consider the role of infection prevention in prompt identification } \\
\text { and mitigating the transmission risk of emerging pathogens }\end{array}$ & Review organizational Ebola preparedness plans & $\checkmark$ & $\checkmark$ \\
\hline $\begin{array}{l}\text { Review the role of emergency management and other stakeholders } \\
\text { in preparing for seasonal epidemics }\end{array}$ & $\begin{array}{l}\text { Review the organizational plans for seasonal and pandemic } \\
\text { influenza }\end{array}$ & $\checkmark$ & $\checkmark$ \\
\hline
\end{tabular}


Table 1. (Continued)

\begin{tabular}{|c|c|c|c|}
\hline Competency & Activities & Rotation & Track \\
\hline \multicolumn{4}{|l|}{ Leadership and program implementation } \\
\hline $\begin{array}{l}\text { Understand hospital administrative structure, and the internal } \\
\text { reporting structure for infection prevention }\end{array}$ & $\begin{array}{l}\text { Review the organization leadership and quality charts } \\
\text { Attend at least } 1 \text { leadership-level meeting }\end{array}$ & $\checkmark$ & $\begin{array}{l}-1 \\
d\end{array}$ \\
\hline Project management: understand the role for a project plan & $\begin{array}{l}\text { Develop a project plan for the quality improvement or research } \\
\text { project of the rotation }\end{array}$ & & $\checkmark$ \\
\hline $\begin{array}{l}\text { Meeting management: understand and practice principles of } \\
\text { successful meeting management }\end{array}$ & $\begin{array}{l}\text { Review with preceptor successful strategies and barriers to efficient } \\
\text { meetings, conduct at least one meeting, and debrief following the } \\
\text { meeting observations of strategies employed and areas for } \\
\text { improvement in meeting management }\end{array}$ & & $\checkmark$ \\
\hline Understand the role of a project/team charter & $\begin{array}{l}\text { Review an existing infection prevention-related project/team } \\
\text { charter, or create a new one for a fellow or team project }\end{array}$ & & $\checkmark$ \\
\hline \multicolumn{4}{|l|}{ Supplemental and advanced topics } \\
\hline \multicolumn{4}{|l|}{ Infection prevention in non-acute-care settings } \\
\hline \multicolumn{4}{|l|}{ Data visualization techniques } \\
\hline \multicolumn{4}{|l|}{ Media training: print, radio, television, and web-based reporting } \\
\hline \multicolumn{4}{|c|}{ Social media and nonconventional methods of professional communication } \\
\hline \multicolumn{4}{|l|}{ Conference presentations (oral and poster) and manuscript writing } \\
\hline \multicolumn{4}{|l|}{ Grant writing/application } \\
\hline Education and mentorship of trainees & & & \\
\hline
\end{tabular}

\section{A proposed structured training model}

To standardize IP\&C education for ID fellows at our institution and to ensure that key competencies are met, we developed a training model enumerating competencies for ID fellows entering IP\&C/HE fields (ie, "track" competencies) and non-IP\&C/HE fields (ie, nested "rotation" competencies), with concrete activities to achieve each (Table 1). The competencies were adapted in part from a published SHEA white paper outlining healthcare epidemiologist skills and competencies, as well as our professional medical education experience. ${ }^{2}$

Critically, these learning goals do not stand alone. During the IP\&C/HE fellowship experience, each fellow is embedded with the IP\&C team, spending dedicated time learning directly from infection preventionists, participating in observations and multidisciplinary work, and conducting analyses and quality improvement projects that promote patient safety. For fellows in fellowship training tracks (eg, antimicrobial stewardship, antibiotic resistance research, transplant ID, HIV and outpatient care, and physicianscientist), the competency activities and all other experiences are tailored to professional goals in these areas (eg, fellows interested in transplant ID may use ventricular assist device-associated infections as a case study to understand device-associated infections more broadly). This standardized, yet flexible, curriculum will help each fellow obtain a comprehensive IP\&C education while allowing focused time on key areas of interest. This approach is mirrored in educational programs for other trainees, such as students pursuing a master's degree in public health.

\section{Continued evolution: A living training collaborative}

In this commentary, we have shared one potential framework toward formalizing the ID fellow's training experience. Others are invited to use the competency checklist in their program (available for download at https://dom.pitt.edu/id/training/fellow shipprograms/idfellowship/programstructure/clineducpathway/). We welcome an ongoing conversation in our IP\&C/HE community about the development of ID fellowship training for nascent hospital epidemiologists, including improvements upon this model, adaptations for other IP\&C and healthcare epidemiology career pathways, and a medical education research agenda testing the effectiveness of this and other educational strategies.

Supplementary material. To view supplementary material for this article, please visit https://doi.org/10.1017/ash.2021.186

\section{Acknowledgments.}

Financial support. No financial support was provided relevant to this article.

Conflicts of interest. All authors report no conflicts of interest relevant to this article.

\section{References}

1. Chiotos K, Rock C, Schweizer ML, et al. Current infection prevention and antibiotic stewardship program practices: a survey of the Society for Healthcare Epidemiology of America (SHEA) Research Network (SRN). Infect Control Hosp Epidemiol 2019;40:1046-1049.

2. Kaye KS, Anderson DJ, Cook E, et al. Guidance for infection prevention and healthcare epidemiology programs: healthcare epidemiologist skills and competencies. Infect Control Hosp Epidemiol 2015;36:369-380.

3. Gupta S, Federman DG. Hospital preparedness for COVID-19 pandemic: experience from department of medicine at Veterans' Affairs Connecticut Healthcare System. Postgrad Med 2020;132:489-494.

4. Banach DB, Johnston BL, Al-Zubeidi D, et al. Outbreak response and incident management: SHEA guidance and resources for healthcare 
epidemiologists in US acute-care hospitals. Infect Control Hosp Epidemiol 2017;38:1393-1419.

5. Wright SB, Ostrowsky B, Fishman N, Deloney VM, Mermel L, Perl TM. Expanding roles of healthcare epidemiology and infection control in spite of limited resources and compensation. Infect Control Hosp Epidemiol 2010;31:127-132.

6. Haley RW. The "hospital epidemiologist" in US hospitals, 1976-1977: a description of the head of the infection surveillance and control program. Report from the SENIC project. Infect Control 1980;1:21-32.

7. Dembry LM, Hierholzer WJ, Jr. Educational needs and opportunities for the hospital epidemiologist. Infect Control Hosp Epidemiol 1996; 17:188-192.

8. ACGME Program Requirements for Graduate Medical Education in Infectious Disease. Accreditation Council for Graduate Medical Education website. https://www.acgme.org/Portals/0/PFAssets/ProgramRequirements/ 146_InfectiousDisease_2020_TCC.pdf?ver=2020-02-17-093422-537. Published 2020. Accessed June 19, 2021.

9. Training courses, SHEA Spring 2021 conference. Society for Healthcare Epidemiology of America website. https://sheaspring.org/program/certificatetracks/. Published 2021. Accessed June 19, 2021.
10. Primer on healthcare epidemiology, infection control, and antimicrobial stewardship. Society for Healthcare Epidemiology of America website. https://learningce.shea-online.org/content/primer-healthcare-epidemiologyinfection-control-antimicrobial-stewardship-0. Published 2020. Accessed June 19, 2021.

11. Fellows' course, 2021. Children's Hospital Colorado. https://www. heicfellowscourse.org/. Published 2021. Accessed June 19, 2021.

12. Joiner KA, Powderly WG, Blaser MJ, et al. Fellowship training in infectious diseases: a report from the regional and national meetings of infectious diseases division chiefs and program directors. Clin Infect Dis 1998;26:1060-1065.

13. Joiner KA, Dismukes WE, Britigan BE, et al. Adequacy of fellowship training: results of a survey of recently graduated fellows. Clin Infect Dis 2001;32:255-262.

14. Sandora TJ, Esbenshade JC, Bryant KA, Pediatric Leadership Council. Pediatric infectious diseases fellowship training in healthcare epidemiology: a national needs assessment. Infect Control Hosp Epidemiol 2013;34: 195-199.

15. Sreeramoju P, Fernandez-Rojas ME. Healthcare epidemiology practicum rotation for postgraduate physician trainees in medicine-infectious diseases. Infect Control Hosp Epidemiol 2013;34:1114-1116. 